\title{
Potential applications of various fungal and bacterial agents in decontamination of agricultural soils: An overview
}

\author{
AnindyaSundar Ray ${ }^{1}$ Jyotirmoy Mondal ${ }^{2}$ \\ ${ }^{1,}$ Department of Botany, SikshaBhavana (Institute of Science), Visva-Bharati, Santiniketan \\ ${ }^{2}$ Department of Agronomy, PalliSikshaBhavana (Institute of Agriculture), Visva-Bharati, Sriniketan
}

\begin{abstract}
This review aims to elaborate the potential applications of different bacterial and fungal species in decontamination of agricultural soils, which have been polluted with the application of continuous and higher doses of inorganic pesticides in the agricultural fields andthis can be considered asa modern phytoremediation approach. Biodegradation is an eco friendly, cost effective, highly efficient approach and can be considered as a superior alternative to physical and chemical methods which are not only technically laborious and costly, also are not sufficient to completely degrade organic and inorganic toxins from the soil. Development of experimental conditions in which all congruent biological agents are applied concurrently may be a promising strategy to enhance biodegradation. Much work remains to be done in carrying out field studies based on laboratory-scale results/experiments using plant-associated endophytic and rhizospheric bacteria to degrade a wide range of toxic compounds of concern in environmental soil before commercially viable systems. Application of strong and effective natural phytotoxins as a potent pesticide is also highly recommended.
\end{abstract}

Keywords: Biodegradation, pesticides, fungi, bacteria, phytoremediation, phytodegradation.

\section{Introduction}

With the gradual development of civilization, man has realized the extent to which the pests harm his crops, annoy him and transmit diseases, both human and those of domestic animals. Neither governments nor individuals can tolerate the loss of crops which cost money, cause diseases and efforts to grow. The rapidly growing industrialization, increasing global population and higher demand of food leads to increaseof food production through intensive agricultural practices, attention of public health and proper utilization natural resources. The improvement of agriculture with advanced agricultural technology to meet this demand, keeping soil in its productive quality plays a dominant role for much of today's productivity. Although wide-scale application of pesticides and herbicides is an essential part of augmenting crop yields; excessive use of these chemicals leads to the microbial imbalance, environmental pollution and health hazards. Huge amount of pesticides are applied annually in modern agriculture to enhance the production through controlling harmful effects caused by the target organisms including insects, fungi, bacteria, viruses as well as grasses grown(commonly known as weeds) in between the economical crops (Liu and Xiong, 2001). Thus, the random and widespread use of man-made, hazardous "xenobiotic" chemicals has led to a remarkable effort to implement new technologies to reduce or eliminate these contaminants from the environment.

Civilization has been combating insects and other pests throughout history. The previous history records many examples of how pests have had major impacts on humans. However, in the past 50 years the use of chemical control has increased tremendously (Day et al., 1997). The modem era of chemical pest control started during World War II, when the much maligned DDT played a major role in the health and welfare of soldiers who used it to control body lice and mosquitoes which transmitted major illnesses. Further developments of pesticides followed. Owing to their low cost, ease of application and their effectiveness, pesticides have become the primary means of controlling pest. However, many pesticides are persistent organic pollutants which remain in an unmodified form in the environment for a prolonged time span. Persistent organic pollutants can also be defined as chemical substances that persist in the environment, bioaccumulate through the food web, and pose a risk of causing adverse effects to human health and the environment. As a consequence, increased use of these chemicals has caused considerable environmental pollution and human health problems (Hayes, 1986; Jitet al., 2011; Vijgenet al., 2011). Hence, contamination of soil, sediment, ground waters and surface waters by persistent organic pollutants is as an important environmental concern world-wide.The term pesticide covers a wide range of compounds including insecticides, fungicides, herbicides, rodenticides, molluscicides, nematicides, plant growth regulators and others. An ideal pesticide should have the ability to destroy target pest quickly and should be able to degrade non-toxic substances as quickly as possiblebut create no harm to the non-target species, including human being. But in reality, this is not the case, so the controversy of use and abuse of pesticides has surfaced. The science is very much clear that even low levels of exposure can harm human health, and children are particularly vulnerable. The ultimate "sink" of the pesticides applied in agricultural field and public health care is soil. Soil being the storehouse of multitudes of microbes, in quantity 
and quality, receives the chemicals in various forms and acts as a scavenger of harmful substances. The abusive use of pesticides for pest control has been widely used in agriculture. However, the indiscriminate use of pesticides has inflicted serious harm and problems to humans as well as to the biodiversity (Gavrilescu, 2005; Hussainet al., 2009). The injudicious uses of pesticides potentially damage the quality of soil which eventually creates damages in ecosystem balance. These ill-effects of pesticides necessitated the research for evolving protection system. Commonly used pollution treatment methods (e.g. land-filling, recycling, pyrolysis and incineration) for the remediation of contaminated sites have also had adverse effects on the environment, which can lead to the formation of toxic intermediates (Debaratiet al., 2005). Moreover, these methods are also very much costly and sometimes difficult to execute, especially in extensive agricultural areas. The main objective of modem pesticide research is to develop new chemicals which attack highly specific targets and disappear rapidly afterwards without accumulating in soil for long time period. One promising treatment method is to exploit the ability of microorganisms to remove pollutants from contaminated sites, an alternative treatment strategy that is effective, minimally hazardous, economical, versatile and environment-friendly, is the process known as bioremediation (Finley et al., 2010).

The pesticides thatenter in the soil environment do get degraded naturally, by a number ofmeans. But it is needed that these pesticides should be degraded in anaccelerated manner. The accelerated degradation of pesticides can beattained either by adapting the type of organisms to a particular pesticideand multiplying their number in the pesticide environment or creatingsuch a condition in the environment that leads to enhanced degradationof the pesticides. However, the required details are not availablefor all the known pesticides and there is still scope for more work to exploresome situation under which a pesticide affect or do not affect a particularsystem. For example, there has been very limited study on the fate ofdegradation products of pesticides and their toxic effects. A number of degradation pathways are incompletely worked out or just proposed; likethe pathway of the TMTD degradation is not fully worked out. Theenzymes responsible for degradation of pesticides have not been studiedin detail. Thus it is of interest to develop methods for degrading andremoving pesticides not only once they have completed their function inthe soil plant system, but also when they accidentally enter soils and waters.

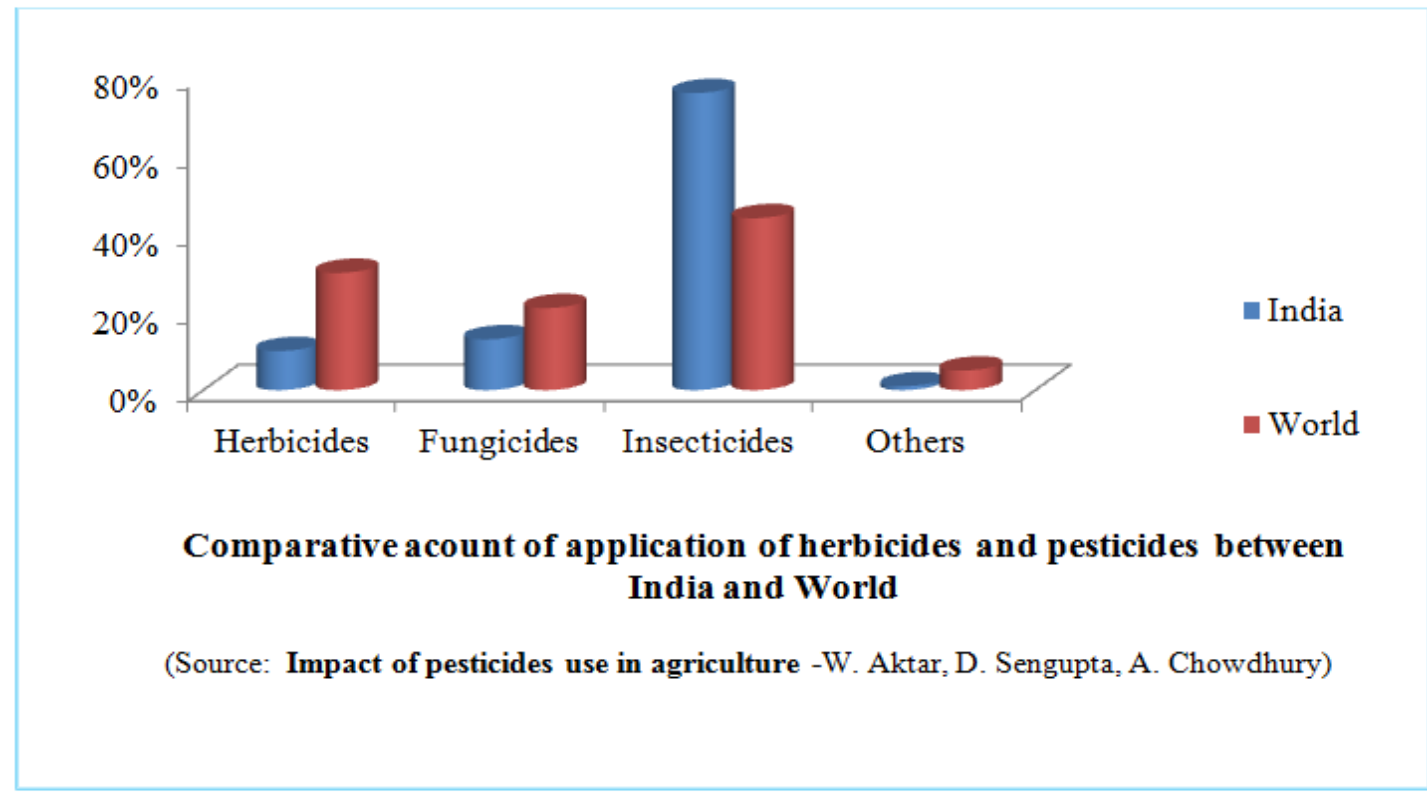

Table 1: Classification of pesticides

\begin{tabular}{|c|c|c|}
\hline $\begin{array}{c}\text { Classification of } \\
\text { Pesticides }\end{array}$ & Types & Examples \\
\hline \multicolumn{3}{|c|}{ Based on chemical structure } \\
\hline \multirow[t]{5}{*}{ I. $\quad$ Main group } & Organochlorine & DDT, BHC, Aldrin, Endosulfun \\
\hline & ii. $\quad$ Organophosphorus & Malathion, Parathion, Monocrotophos \\
\hline & iii. $\quad$ Carbamates & Aldicarb, Carbafuran, Carbaryl \\
\hline & iv. $\quad$ Pyrethroids & Aldrin, Cypermethrin \\
\hline & $\begin{array}{|ll|}\text { v. } & \text { Nionicotonides } \\
\end{array}$ & Acetamiprid, Imidiclorprid \\
\hline \multirow[t]{4}{*}{ I. Other groups } & i. $\quad$ Organotin compounds & Triphenyltin acetate, \\
\hline & ii. Organomercurial compounds & Ethyl mercuric chloride, Phenyl mercuric brmide \\
\hline & iii. Dithiomate fungicide & Mancozeb, Zineb, Maneb \\
\hline & Chlorifenoxy compounds & 2,4-D, 2,4,5-T, DCPA, MCPP \\
\hline
\end{tabular}




\begin{tabular}{|c|c|c|c|}
\hline & & Benzimidiazole compounds & Benomyl, Carbendiazim \\
\hline & & Dipyridiliums & Paraquat, Diquat \\
\hline & & Miscellaneous & Bromoxin. Simazine \\
\hline \multirow{3}{*}{$\begin{array}{l}\text { Other classification of } \\
\text { pesticides }\end{array}$} & & Allephatic compounds & Malathion, Glyphosate, Maneb \\
\hline & & Aromatic compounds & 2,4-D, Diuron \\
\hline & & Heterocyclic ring compounds & Nicotin, Captan, Atrazine \\
\hline \multirow[t]{5}{*}{ Based on mode of action } & & Nerve poison & $\begin{array}{l}\text { Organanochlorin, organophosphate } \\
\text { compoundsandCarbamates }\end{array}$ \\
\hline & & Anticoagulants & Warfarin \\
\hline & & Juvenile hormons & Azadirachtin, Fenoxycarb \\
\hline & & Antifeedents & $\begin{array}{l}\text { Neem citrus derivatives limonoids \& their synthetic } \\
\text { derevatives }\end{array}$ \\
\hline & & Repellents & Neem oil, Citronella oil \\
\hline \multirow[t]{2}{*}{ Based on pesticide action } & & Stomach action & DDT, BHC, Metolachlor \\
\hline & & Contact insecticide & Aldrin, Parathion \\
\hline \multirow{5}{*}{$\begin{array}{l}\text { Chemical classification of } \\
\text { organochlorine pesticides }\end{array}$} & & Cyclodiene compounds & Aldrin, Endosulfan \\
\hline & & Halogenated aromatic & DDT, Kelthane \\
\hline & & Compounds & Chlorobengylate \\
\hline & & Cycloparaffins & $\mathrm{HCH}$, Lindane \\
\hline & & Chlorinated terpens & Polychlorcamphenes, Polychlorpinenes \\
\hline
\end{tabular}

Table 2: Different types of Pesticides, their targets and some important examples

\begin{tabular}{|c|c|c|c|}
\hline Number & Pesticides & Targets & Examples \\
\hline 1 & Algaecide or Algicide & Algae & $\begin{array}{l}\text { Benzalkonium chloride, Bethoxazin, Copper sulfate, Cybutryne, } \\
\text { Dichlone, Dichlorophen, Diuron, Fentin, Endothal hydrated lime, } \\
\text { Isoproturon, Methabenzthiazuron, Nabam, Oxyfluorfen, } \\
\text { Pentachlorophenyl, laurate, Quinoclamine, Quinonamid, Simazine, } \\
\text { Terbutryn, Tiodonium }\end{array}$ \\
\hline 2 & Acaricide or Miticide & $\begin{array}{l}\text { Mites or } \\
\text { Ticks }\end{array}$ & Permethrin, Ivermectin, Carbamate, Formamidine, Dicofol \\
\hline 3 & Avicide & Birds & Strychnine, DRC-1339, Avitrol, Parathione, Chloralose \\
\hline 4 & Bactericide or Bacteriacide & Bacteria & $\begin{array}{l}\text { Disinfectants(hypochlorites, chloramines, sodium perborate, ethanol, } \\
\text { phenols), Antiseptics, Antibiotics(penicillin, daptomycin) }\end{array}$ \\
\hline 5 & Virucide & Virus & $\begin{array}{l}\text { Cyanovirin-N, Griffithsin, Scytovirin, EP } 0978289 \text { A1 with iodine, } \\
\text { NVC-422, Zonrox bleach, Interferon, Lysol }\end{array}$ \\
\hline 6 & Fungicide or Mycocide & Fungus & Amphotericin B, Candicin, Nystatin, Rimocidin \\
\hline 7 & Insecticide & Insects & DDT, Sarin, Pyrethroids \\
\hline 8 & Herbicide & Weeds & $\begin{array}{l}\text { 2,4-D, Imidazolinones, Triazolopyrimidines, } \\
\text { Pyrimidinyloxybenzoates, Sulfonylamino carbonyl triazolinones }\end{array}$ \\
\hline 9 & Herpecide & Reptiles & \\
\hline 10 & Larvicide & Insect larva & Methoprene, Temephos \\
\hline 11 & Molluscicide & $\begin{array}{l}\text { Snail and } \\
\text { slugs }\end{array}$ & Metaldehyde, Metal salts, Methiocarb \\
\hline 12 & Nematicide & Nematodes & Carbamate \\
\hline 13 & Ovicide & Eggs & \\
\hline 14 & Piscicide & Fish & Rotenone, Saponins, TFM, Niclosamide and Antimycin A (Fintrol) \\
\hline 15 & Rodenticide & Rodents & $\begin{array}{l}\text { Aluminium phosphide, Calcium phosphate, Zinc phosphate, Arsenic } \\
\text { trioxide, Endrin }\end{array}$ \\
\hline 16 & Biopesticide & $\begin{array}{l}\text { Green pest } \\
\text { control }\end{array}$ & Algae, Fungi, Bacteria, Higher plants, etc. \\
\hline
\end{tabular}

\section{Bioremediation}

Bioremediation is the process by which living organisms degrade hazardous pollutants.Among different bioremediation methods, microbial metabolism is accepted as a safer and efficient tool for the removal of many pollutants. The relatively inexpensive technology of bioremediation for reclaiming chemically contaminated land has therefore been steadily gaining acceptance since 1980's. Different bioremediation approaches have been successfully applied for the removal of soils contaminated with a variety of xenobiotic compounds (Newcombe and Crowley, 1999; Top et al., 1999; Cunningham and Philip, 2000; Juhaszet al., 2000; Runes et al., 2001; Manzanoet al., 2003). Bioremediation may be applied after excavation of polluted site material and transport to a controlled environment (ex situ) or, under relatively natural conditions in the field (in situ).

\section{Potential of Microbial Agents in Decontamination of Soil}

Although pesticides are known to be degraded by some selected microorganisms, but the use of microorganisms for the detoxification of pollutants in the environment is a recently acknowledged feasibility. The potential problems involved with the use of microorganisms in the environment have been discussed in reference to oil clean up (Cobetet al., 1973; Zobell, 1973). The use of microbial populations for the cleanup of 
oil spills has been reported. Some oil degrading microbial preparations have been reported to be commercially available (Atlas and Bartha, 1973). Only in the past twenty years or so, have investigations shown that soil undesirably contaminated with a pesticide could possibly be decontaminated by inoculation with specifically adapted microorganisms. Several soil bacteria can degrade 2,4-D (2,4-dichloro-phenoxyacetic acid) accumulated in the soil by microbial detoxification procedures (Audus 1964; Loos 1975; Smith 1989). Several Arthrobacter, Flqvobqcterium, and Pseudomonas spp. have been isolated from soil (Loos 1975) and used in liquid media to determine the metabolic pathway of 2,4-D solubilization and ultimate detoxification (Audus 1964; Evans et al. 1971; Loos 1975). With at least some of the degrading bacteria, release of inorganic chloride indicates complete breakdown of the 2,4-D molecule (Loos 1975; Kelly et al. 1989). Audus (1950) perhaps, first of all demonstrated that bacteria adapted to utilize the herbicide 2,4-D could accelerate the disappearance of this compound from soil. In another experiment Macrae and Alexander (1965) made an attempt to protect the seeds of alfalfa from the herbicide by inoculating the heavy suspension of Flavobacteriumsp. capable of utilizing this herbicide. Kearney et al. (1969) showed accelerated DDT disappearance from flooded soil inoculated with DDT acclimatedEnterobacteraerogenes. Daughton and Hsieh (1977) reported accelerated degradation of parathion in flooded and non-flooded soils by inoculation with parathion acclimated bacterial culture. Shirkot and Gupta (1985) have reported accelerated degradation of TMTD in soil by inoculation with TMTD-utilizing bacteria. The TMTD degrading Pseudomonas aeruginosawas extremely effective in rapidly degrading 300 to 500 ppm of TMTD in different soils within 3 weeks under laboratory conditions. Most of these studies have been carried out in the laboratory or pot house using various approaches including immobilized cells or enzymes, fixed microbial films, soil columns, and conventional waste water processes. In the case of soil, inoculation with natural isolates or constructed strains and stimulation of indigenous microbial populations have been the major approaches to removal of pesticides. Sims et al. (1986) have compiled a comprehensive list of methods for use in surface soil decontamination. Fixed films of bacterial cells on a variety of supports have been found successful in removing a wide range of pesticides and structurally related substances from water and waste water. Bouwer and McCarty (1982) reported the removal of chlorinated benzenes and aliphatics by a granular activated carbon column (CAC) with biological activity over a 2 year period at an efficiency level of 95 to 98 per cent. Smith and Mortensen (1991) carried out the degradation of 2,4-D residues using soil bacterium, Pseudomonas testosteroniin a sprayer tank containing an aerated solution of simple mineral salts and 2,4-D amine formulations. The organism used the herbicide as a carbon source. Rozgaj (1994) has also reported that pesticide degradation is mainly by biological means involving microorganisms (bacteria and fungi) in a contaminated system.

The biological methods are advantageous to decontaminate areas that have been polluted by pesticides. These methods consider the thousands of microorganisms in the environment that in order to survive seek for alternatives to eliminate the pesticides that were sprayed. It was well established that microbes have the ability to transform and/or degrade a number of chemical agents which are causing severe damage in the environment. Realizing that fact, scientists have been exploring the microbial diversity, particularly of contaminated areas in search of organisms that can degrade a wide range of pollutants. Hence, biotransformation of organic contaminants in the natural environment has been extensively studied to understand microbial ecology, physiology and evolution due to their bioremediation potential (Mishra et al., 2001). The biochemical and genetic basis of microbial degradation has received considerable attention. Several genes/enzymes, which provide microorganisms with the ability to degrade organopesticides, have been identified and characterized. Many native microorganisms develop complex and effective metabolic pathways that permit the biodegradation of toxic substances that are released into the environment. Microbial degradation of chemical compounds in the environment is an important route for the removal of these compounds. The biodegradation of these compounds, i.e., pesticides, is often complex and involves a series of biochemical reactions. Although many enzymes efficiently catalyze the biodegradation of pesticides, the full understanding of the biodegradation pathway often requires new investigations. Several pesticide biodegradation studies have shown only the total of degraded pesticide, but have not investigated in depth the new biotransformed products and their fate in the environment. On account of the grave risks synthetic pesticides pose to the organisms, there is an incessant search for pesticide safety and for the development of sustainable agriculture. The biological pesticides are based on natural compounds that effectively control the infestation of pests in agriculture. The advantage is that, contrary to synthetic pesticides, they are efficient and does not cause collateral damage (Fravel, 2005; Gerhardson, 2002; Raaijmakerset al., 2002; Meleiroet al., 2010).

Among differentorganochlorine (OC) insecticides, used successfully in controlling a number of diseases, such as malaria and typhus, were banned or restricted after the 1960s in most of the technologically advanced countries. The introduction of other synthetic insecticides - organophosphate (OP) insecticides in the 1960s, carbamates in 1970s and pyrethroids in 1980s and the introduction of herbicides and fungicides in the 1970s-1980s contributed greatly to pest control and agricultural output. Ideally a pesticide must be lethal to the targeted pests, but not to non-target species, including man. Unfortunately, this is not the case, so the 
controversy of use and abuse of pesticides has surfaced. The rampant use of these chemicals, under the adage, "if little is good, a lot more will be better" has played havoc with human and other life forms.

\section{Role of fungi}

Fungi degrade pesticides by introducing minor structural changes to the pesticides rendering it non toxic and are released to soil, where it is susceptible to further biodegradation by bacteria. Several fungi such as Agrocybesemiorbicularis, Auriculariaauricula, Coriolusversicolor, Dichomitussqualens, Flammulinavelupites, Hypholomafasciculare, Pleurotusostreatus, Stereumhirsutum, and Avatha discolor have shown their ability to degrade various pesticide groups like phenylamide, triazine, phenylurea, dicarboximide, chlorinated and organophosphorus compounds (Bending et al., 2002). According to Quintero et al., 2007 several classes of pesticides such as lindane, atrazine, diuron, terbuthylazine, metalaxyl, DDT, gamma-hexachlorocyclohexane $(\mathrm{g}-\mathrm{HCH})$, dieldrin, aldrin, heptachlor, chlordane, lindane, mirex, etc. have been degraded to different extent by white-rot fungi. It is also well established that fungi isolated from oil spill environment can reduce oil pollution (Das and Chandran, 2011).

Pure cultures of the lignin-degrading fungi Phanerochaetechrysosporiumand Trameteshirsutmhave been shown to degrade Lindane(Bumpuset al., 1985; Kennedy et al., 1990; Mouginet al., 1997; Singh and Kuhad, 1999). The proposed mechanism for degradation was similar to that of lignin degradation, i.e. multiple non-specific oxidative reactions resulting from generation of carbon-centered free-radicals (Bumpuset al., 1985). The ability of several white rot fungi (Pleurotussajorcaju, PleurotusfloridaandPleurotuseryngli) to degrade Lindane was reported by Arisoy (1998).

\section{Role of bacteria}

Most bacterial species which degrade pesticides belong to the genera Flavobacterium, Arthrobacter, Azotobacter, Burkholderia and Pseudomonas. The nature of degradation varies among species and the target compound. Pseudomonas sp. and Klebsiellapneumoniae have been shown to possess hydrolytic enzymes that are capable of breaking down s-triazine herbicides, such as atrazine. Similarly, a number of enzymes such as oxygenases, hydroxylases, hydrolases and isomerases present in Pseudomonas sp. and Alcaligenessp. have been shown to degrade herbicide 2,4-D(Mulbry and Kearney, 1991). In soil environment, due to the limiting environmental conditions and nature of the pesticides, most of the pesticides undergo partial degradation leading to the formation and accumulation of metabolites in the soil system. These metabolites are sometimes more toxic and less soluble than the parent compound which may inhibit the microbial population in the soil and further reduce the degradation of the pesticide resulting in the partial degradation of the pesticide. For example, degradation of endosulfan in soil by fungi and bacteria follows such a pathway via oxidation and hydrolysis leading to the formation of toxic endosulfan sulfate and less toxic endosulfandiol (Weir et al., 2006). Best example for partial degradation is DDT, which undergoes the degradation to form metabolites like DDD and DDE that are toxic and more persistent than the parent compound (Foghtet al., 2001). Introducing microbial population which can degrade the pesticides completely and by optimizing the environmental condition can enhance the degradation of pesticides and its metabolites in the soil. Microbial degradation of most of the recalcitrant organic compounds is limited by the presence of anionic species in the compound. The anions like chloride, sulphate etc. are strongly bonded to the hydrocarbon ring which prevents the microbes from attacking the ring structure. This may be due to increased toxicity of anionic group (Julia et al., 2001).

\section{Conclusion}

About $30 \%$ of agricultural produce is lost due to pests. Hence, the use of pesticides has become indispensable in agriculture. The objective in modem pesticide research is to develop chemicals which attack highly specific targets and disappear rapidly afterwards. Since these pesticides do not disappear rapidly, they have the ability to alter the ecological balance by attacking the non target system in the soil environment. One of the foremost effect of pesticides is inhibition of microbial population (Tu, 1991; Martinez-Toledo et al, 1992; Gonzalez- Lopez et al, 1993) in soil which may lead to elimination, decrease or modification of soil biological processes such as Nitrification (Tu, 1989; Lodhiet al, 1994), Ammonification (Schuster and Schroder, 1990; Lafranceet al., 1992), Nitrogen fixation (Cemakovaet al., 1993; Sarafet al., 1994) etc. whichare essential for soil fertility. The biochemical and genetic basis of microbial degradation has received considerable attention. Several genes/enzymes, which provide microorganisms with the ability to degrade organopesticides, have been identified and characterized. Thus, microorganisms provide a potential wealth in biodegradation. The ability of these organisms to reduce the concentration of xenobiotics is directly linked to their long-term adaptation to environments where these compounds exist. Moreover, genetic engineering may be used to enhance the performance of such microorganisms that have the preferred properties, essential for biodegradation (Schrollet al., 2004). Exploitation of the ability of microorganisms to remove pollutants from contaminated sites, an 
alternative treatment strategy that will be very much effective, minimally hazardous, economical, versatile and environment-friendly and it can be treated as a smart practice of bioremediation (Finley et al., 2010).

\section{References}

[1]. Aktar, M. W., Sengupta, D., \& Chowdhury, A. (2009). Impact of pesticides use in agriculture: their benefits and hazards. Interdisciplinary Toxicology, 2(1), 1-12. http://doi.org/10.2478/v10102-009-0001-7.

[2]. Atlas, R.M. and Bartha, R. 1973. In : The Microbial Degradation of Oil/ Pollutants (D.G. Ahearn and S.P. Meyers, Eds.) pp. 28389. Baton Rouge La., Louisiana State University.

[3]. Audus, L. J. (1964). Herbicide behaviour in the soil. Pages 163-206 in L. J .Audus, ed. The physiology and biochemistry of herbicides. Academic Press, Inc., London, U.K.

[4]. Audus, L.J. 1950. Biological detoxification of 2,4-dichlorophenoxyacetic acid in soils : Isolation of the effective organism. Nature (London), $166: 356$

[5]. Benimeli, C.S.; Fuentes, M.S.; Abate, C.M. \& Amoroso, M.J. (2008). Bioremediation of Lindane-Contaminated Soil by Streptomyces sp. M7 and its Effects on Zea mays Growth, International Biodeterioration\& Biodegradation, Vol. 61, (September 2007), pp.233-239, ISSN 0964-8305.

[6]. Bouwer, E.J. and McCarty, P.L. 1982. Removal ot trace chlorinated organics by activated carbon and lixed film bacteria. Environment Science and Technology. $16: 830$

[7]. Bumpus, J.A., Tien, M., Wright, D. and Anst, S.D. (1985) Oxidation of persistent environmental pollutants by a white rot fungus. Science. 228: 1434-1436.

[8]. Bumpus, J.A.; Powers, R.H. \& Sun, T. (1993). Biodegradation of DDE (1,1-Dichloro-2,2-bis(4- hlorophenyl)ethane) by Phanerochaetechrysosporium, Mycological Research, Vol. 97, pp.95-98, ISSN 0953-7562.

[9]. Cernakova, M. 1993. Eflectot the insecticide Neramelrine EK-15 on activities of soil microorganisms. Folia Microbiologica. (4): 331.

[10]. Chanika, E.; Georgiadou, D.; Soueref, E.; Karas, P.; Karanasios, E.; Nikolaos, G.T.; Tzortzakakis, E.A. \&Karpouzas, D.G. (2011). Isolation of Soil Bacteria Able to Hydrolyze Both Organophosphate and Carbamate Pesticides, Bioresource Technology, Vol.102, (February 2011), pp. 3184-3192, ISSN 09608524

[11]. Cobet, A.B., Guard, FI.E. andChatigny, M.A. 1973. In : The microbial degradation of oil pollutants (D.G. Ahearn and S.P. Meyers eds.), pp. 80-87. Baton Rouge*, La., Lousiana State University.

[12]. Crawford, R.L. \&Mohn, W.W. (1985). Microbiological Removal of Pentachlorophenol from Soil Using a Flavobacterium, Enzyme and Microbial Technology, Vol. 7, No. 12, (December 1985), pp.617-620, ISSN 0141-0229.

[13]. Cunningham, S. D. Ow DW. (1996). Promise and prospects of phytoremediation. Plant Physiol.;110:715_9.

[14]. Das, N. Chandran, P. 2011. Microbial degradation of petroleum hydrocarbon contaminants: An overview, Biotechnol. Res. Inter, 1 - 13 .

[15]. Daughton, C.G. and Hsieh, D.P.H. 1977. Accelerated parathion degradation in soil by inoculation by parathion utilizing bacteria. Bulletin of Environmental Contamination and Toxicology. $18: 48$.

[16]. Day, L.G. Hock, W.K. and McAlpine, G.(1997) Farm Chemicals Manual: A guide to safe use and handling. Agsafe Limited, North Sydney (Australia).

[17]. Debarati, P. Gunjan, P. Janmejay, P. Rakesh,V.J.K. (2005). Accessing Microbial Diversity for Bioremediation and Environmental Restoration, Trends in Biotechnology, V.23, No.3, (March 2005), pp.135-142, ISSN 0167-9430.

[18]. De Schrijver, A. \& De Mot, R. (1999). Degradation of Pesticides by Actinomycetes, Critical Review in Microbiololy, Vol. 25, No. 2, pp. 85-119, ISSN 1040-841X.

[19]. Evans, W. C., Smith, B. S. W., Fernley, H. N. and Davies, J.1. 1971. Bacterial metabolism of 2,4-dichlorophenoxyacetate. Biochem. J. 122:543-55 1 .

[20]. Fang, H.; Dong, B.; Yan, H.; Tang, F. \&Yunlong, Y. (2010). Characterization of a Bacterial Strain Capable of Degrading DDT Congeners and its Use in Bioremediation of Contaminated Soil, Journal of Hazardous Material, Vol. 184, Nos.1-3, (August 2010), pp.281-289, ISSN 0304-3894.

[21]. Foght, Julia. April, Trevor. Biggar, Kevin. \&Aislabie, Jackie. 2001. Bioremediation of DDT-Contaminated Soils: A Review. 5 : $225-246$

[22]. Gary, D. Bending. Maxime, Friloux. And Allan, Walker. 2002. Degradation of contrasting pesticides by white rot fungi and its relationship with ligninolytic potential. Horticulture Research International, 59-63.

[23]. Gavrilescu, M. (2005). Fate of Pesticides in the Environment and its Bioremediation, Engineer in Life Science, Vol.5, No. 6, (December 2005), pp. 497-526, ISSN 1618-2863.

[24]. Gonzalez-Lopez, J., Martinez-Toledo, M.V., Rodelas, B. and Salmeron, V. 1993. Studies on the effects of the insecticides phorate and malathion on soil microorganisms. Environmental toxicology and Chemistry. 12 (7): 1209.

[25]. Hayes, W.J. (1986) Pesticide studies in man. Williams \& Wilkins, Baltimore (USA).

[26]. Hodge, A.; Paterson, E.; Grayston, S. J.; Campbell, C. D.; Ord, B.G.; Killham, K. 1998. Characterisation and microbial utilisation of exudate material from the rhizosphere of Loliumperenne grown under CO2 enrichment. Soil Biology and Biochemistry, 30 (8/9): 1033-1043.

[27]. Hussain, S.; Siddique, T.; Arshad, M. \&Saleem, M. (2009). Bioremediation and Phytoremediation of Pesticides: Recent Advances, Critical Review in Environmental Science and Technology, Vol. 39, No. 10, pp. 843-907, ISSN 1064-3389.

[28]. Jit S, Dadhwal M, Kumari H, Jindal S, Kaur J, Lata P, Niharika N, Lai D, Garg N, Gupta SK, Sharma P, Bala K, Singh A, Vijgen J, Weber R, Lai R. (2011) Evaluation of hexachlorocyclohexane contamination from the last lindane production plant operating in India. Environ SciPollut Res Int. 18(4):586-597.

[29]. Kaufman, D.D. \& Blake, J. (1973). Microbial Degradation of Several Acetamide,Acylanilide, Carbamate, Toluidine and Urea Pesticides. Soil Biology \& Biochemistry, Vol.5, No. 3,(November 1972), pp. 297-308, ISSN 0038-0717.

[30]. Kearney, P.C., Plimmer, J.R. and Guardia, F.S. 1969. Mixed chloroazobenzenelormation in soil. Journal of Agriculture Food Chemistry. $17: 1418$.

[31]. Kelly, M. P., Hallberg, K. B. and Tuovinen, O. H. 1989. Biological degradation of 2,4dichlorophenoxyacetic acid: Chloride mass balance in stirred tank reactors. Appl. Environ. Microbiol. 55: 2717 -27 19.

[32]. Kennedy, D.W., Aust, S.D. and Bumpus, J.A. (1990) Comparative biodegradation of alkyl halide insecticides by the white rot fungus, Phanaerochaetechryososporium (BKM-F-1767). Appl. Environ. Microbiol. 56: 2347-2352. 
[33]. Kim, I.S.; Ryu, J.Y.; Hur, H.G.; Gu, M.B.; Kim, S.D. \& Shim, J.H. (2004). Sphingomonassp. Strain SB5 Degrades Carbofuran to a New Metabolite by Hydrolysis at the Furanyl Ring, Journal of Agricultural and Food Chemistry, Vol. 52, No. 8, (April 2004), 2309-2314, ISSN 0021-8561.

[34]. Lacayo, R.M., Terrazas, E., van Bavel, B. \&Mattiasson, B. (2006). Degradation of Toxaphene by Bjerkanderasp. Strain BOL13 Using Waste Biomass as a Co-substrate, Applied Microbiology and Biotechnology, Vol. 71, No.4, (May 2005), pp.549-554, ISSN $0175-7598$.

[35]. Lafrance, P., Salvano, E. and Villenenve, J.P. 1992. Effect of the herbicide atrazine on soil respiration and the ammonification of organic nitrogen in an incubated agricultural soil. Canadian Journal of Soil Science. 72 (1): 1.

[36]. Liu YY, Xiong Y (2001). Purification and characterization of a dimethoate-degrading enzyme of AspergillusnigerZHY256 isolated from sewage. Appl. Environ. Microbiol., 67: 3746-3749.

[37]. Lodhi, A., Malik, N.N. and Azam, F. 1994. Effect of baythroid on nitrogen transformations in soil. Biology and Fertility of Soils. 17 (3): 173.

[38]. Loos, M. A. Ins. Phenoxyalkanoic acids. Pages 1-128 in P. C. Kearney and D. D. Kaufman, eds. Herbicides: chemistry, degradation, and mode of action. Vol. 1. 2nd ed. Marcel Dekker. Inc.. New York. NY.

[39]. Macrae, I.C. and Alexander, M. 1965. Microbial degradation of selected herbicides in soil. Journal of Agriculture Food Chemistry, $13: 72$.

[40]. María, J, Quintero. Douglas, Maya. Miguel, Arévalo-Rodríguez. Ángel, Cebolla. andSebastián, Chávez. 2007. An improved system for estradiol-dependent regulation of gene expression in yeast. Microbial Cell Factories, 6-10.

[41]. Martinez-Toledo, M.V., Salmeron, V. and Gonzalez-Lopez, J. 1992. Effect of an organophosphorus insecticide, profenofos, on agricultural soil microflora. Chemosphere. 24 (1): 71.

[42]. Matsumura, F.; Boush, G. M. \& Tai, A. (1968). Breakdown of Dieldrin in the Soil by a Microorganism, Nature, Vol. 219, No. 5157, (August 1968), pp.965-967, ISSN 0028-0836.

[43]. Meleiro Porto, A. L., ZelayaránMelgar, G., ConsiglioKasemodel, M., \&Nitschke, M. (2010). Biodegradation of Pesticides. Pesticides in the Modern World - Pesticides Use and Management, 407-439. http://doi.org/10.5772/17686.

[44]. Mougin, C., Pericaud, C., Dubroca, J. and Asther, M. (1997) Enhanced mineralization of Lindane in soils suplemented with the white rotbasidiomycetePhanaerochaeechrysosporium. Soil Biol. Biochem. 29: 1321-1324.

[45]. Mulbry, W. Kearney, P, C. 1991. Degradation of pesticides by microorganisms and the potential for genetic manipulation. Crop Protection, 10: 334-346.

[46]. Mulbry, W.W.\&Karns, J.S. (1989). Parathion Hydrolase Specified by the FlavobacteriumopdGene: Relationship Between the Gene and Protein, Journal of Bacteriology, Vol.171, No.12, (December 1989), pp.6740-6746, ISSN 0021-9193.

[47]. Ortega, N.O., Nitschke, M., Mouad, A.M., Landgraf, M.D., Rezende, M.O.O., Seleghim, M.H.R., Sette, L. D., Porto, A.L.M. (2011). Isolation of Brazilian Marine Fungi Capable of Growing on DDD Pesticide, Biodegradation, Vol. 22, (June 2010), pp. 4350, ISSN 0964-8305.

[48]. Patil, K.C.; Matsumura, F. \&Boush, G.M. (1970). Degradation of Endrin, Aldrin, and DDT by Soil Microorganisms, Journal of Applied Microbiology, Vol. 19, No. 5, (May 1970), pp.879-881, ISSN 1365-2672.

[49]. Pesce, S.F. \&Wunderlin, D.A. (2004). Biodegradation of Lindane by a Native Bacterial Consortium Isolated from Contaminated River Sediment, International Biodeterioration\& Biodegradation, Vol. 54, No.4, (January 2004), pp. 255-260, ISSN 0964-8305.

[50]. Resnick, S. M.; Chapman, P. J. 1994. Physiological properties and substrate specificity of pentachlorophenol-degrading Pseudomonas species. Biodegradation, 5: 47-54.

[51]. Rigas, F.; Dritsa, V.; Marchant, R.; Papadopoulou, K.; Avramides, E.J. \&Hatzianestis, I. (2005). Biodegradation of Lindane by Pelourotusostreatusvia Central Composite Design, Environmental International, Vol. 31, No.2, (December 2004), pp.191-196, ISSN 0160-4120.

[52]. Rozgaj, R. 1994. Environmental microbial degradation of xenobiotics. ArchivZaHigijenuRada i Toksikologija. 45 (2) : 189

[53]. Saber, D.; Crawford, R. L. 1985. Isolation and characterization of Flavobacterium strains that degrade pentachlorophenol. Applied Environmental Microbiology, 50 (6): 1512-1518.

[54]. Saraf, M., Kandelwal, A., Sawhney, R. and Maheshwari, D.K. 1994. Effect of carbaryl and 2,4-D on growth, nitrogenase and uptake hydrogenase activity in agar culture and root nodules formed by Bradyrhizobiumjaponicmn. Microbiological Research.149 (4): 401.

[55]. Schuster, E. and Schroder, D. 1990. Side-effects of sequentially-applied pesticides on non-target soil microorganisms : Field experiments. Soil Biology Biochemistry. 22 (3): 367

[56]. Serdar, C.M.; Murdock, D.C.; Rohde, M.F. (1989). Parathion Hydrolase Gene from Pseudomonas diminutaMG: Subcloning, Complete Nucleotide Sequence, and Expression of the Mature Portion of the Enzyme in Escherichia coli, Nature Biotechnology, Vol.7, pp.1151-1155, ISSN 1087-0156.

[57]. Shirkot, C.K. and Gupta, K.G. 1985. Accelerated tetramethylthiuramdisulphide (TMTD) degradation in soil by inoculation with TMTD utilizing bacteria. Bulletin of Environmental Contamination and Toxicology. $35: 354$.

[58]. Sims, R., Sorensen, D., Sims, J., Mclean, J., Mahmood, R., DuPont, R., Jurinak, J. and Wagner, K. 1986. Contaminated surface soils in-place treatment techniques. Noyes Publications, Park Ridge, N.J.

[59]. Smith, A. E. 1989. Degradation, fate, and persistence of phenoxyalkanoic acid herbicides in soil. Rev. Weed Sci. 4: 1-24.

[60]. Smith, A.E. and Mortensen, K. 1991. Degradation of waste 2,4-D using a soil bacterium in a sprayer tank system. Canadian Journal of Soil Science. $71: 243$.

[61]. Stanlake, G.J. \& Finn, R.K. (1982). Isolation and Characterization of a Pentachlorophenol- Degrading Bacterium, Applied Environmental Microbiology, Vol. 44, (No. 6, December 1982), pp.1421-1427, ISSN 0099-2240.

[62]. Tu, C.M. 1989. Effects of some experimental insecticides on microbial activities in mineral and organic soils. Journal of Environmental Sciences and Health. B24 (1): 57.

[63]. Tu, C.M. 1991. Effect of some technical and formulated insecticides on microbial activities in soil. Journal of Environmental Sciences and Health. B26 (5 and 6): 557.

[64]. Vijgen John, P. C. Abhilash, Yi Fan Li, Rup Lai, Martin Forter, Joao Torres, Nandita Singh, Mohammad Yunus, ChongguoTian, Andreas Schaffer, Roland Weber, (2011). Hexachlorocyclohexane (HCH) as new Stockholm Convention POPs-a global perspective on the management of Lindane and its waste isomers. Environ SciPollut Res. 18:152-162.

[65]. Wedemeyer, G. (1967). Dechlorination of 1,1,1-Trichloro-2,2-bis(p-chlorophenyl)ethane by Aerobacteraerogene, Journal of Applied Microbiology, Vol. 15, No. 3, (May 1967), pp.569-574, ISSN 1365-2672.

[66]. Weir, Laura, G. Harsh, P. Bais, Tiffany, L. Perry, Simon, Gilroy. and Jorge, M, Vivanco. 2006. The roll of root exudates in rhizosphere interactions with plants and other organisms. Annual Review of Plant Biology. 57: 233-266 
[67]. Xiao, P., Mori, T., Kamei, I. \& Kondo, R. (2011). Metabolism of Organochlorine Pesticide Heptachlor and its Metabolite Heptachlor Epoxide by White-rot Fungi, Belonging to Genus Phlebia, Microbiology Letters, Vol. 314, No.2, (January 2011), pp.140-146, ISSN 1574-6968.

[68]. Yuanfan, H; Jin, Z.; Qing, H.; Qian, W.; Jiandong, J.; Shunpeng, L. (2010). Characterization of a Fenpropathrin-Degrading Strain and Construction of a Genetically Engineered Microorganism for Simultaneous Degradation of Methyl Parathion and Fenpropathrin, Journal of Environmental Management, Vol.91, No.11 (November 2010), pp.2295-2300, ISSN 0301-4797.

[69]. Zhang, H.; Yang, C.; Li, C.; Li, L.; Zhao, Q.; Qiao, C. (2008). Functional Assembly of a Microbial Consortium with Autofluorescent and Mineralizing Activity for the Biodegradation of Organophosphates, Journal of Agricultural Food and Chemistry, Vol.56, No.17, (September 2008), pp.7897-7902, ISSN 0021-8561.

[70]. Zobell, C.E. 1973. In : The microbial degradation of oil pollutants (D.C. Ahearm and S.P. Meyers eds.) pp. 3-16. Baton Rouge, La., Louisiana State University. 